\title{
The Study of Relationship Between Pedestrian and Safety based on the Theory of Planned Behaviour at Batu Pahat, Johor
}

\author{
M. A. M. Bilema ${ }^{1}$, M. M. Haurula ${ }^{1}$, and R. Rahman ${ }^{1, *}$ \\ ${ }^{1}$ Department of Highway and Traffic Engineering, Faculty of Civil and Environmental Engineering, \\ Universiti Tun Hussein Onn Malaysia, 86400 Parit Raja, Johor, Malaysia
}

\begin{abstract}
Pedestrian are among those who were contributed to the increase of road accidents and identified as vulnerable rod user in the country. Various aspects and factors that lead to the accident among the pedestrian and other road users are needed to be studied, so that the safety all road user should be improved. This study was conducted to identify the characteristics of user demographic in terms of age, gender, employment and others. In addition, the characteristics and the perception of pedestrians were also evaluated in order to achieve the objectives of this study. The observational study was carried out to the users on the usage of pedestrian facilities. The study was focused in the city area of Batu Pahat. The type of pedestrian facilities included pedestrian walkaways, pedestrian bridges and zebra crossings. A total of 200 sets of survey questions were distributed among respondents and analyzed using Statistical Package for Social Science (SPSS) based on the behavioral model called the multiple regression analysis. The correlation analysis shows that attitudes have a significant effect on the safety of pedestrians and other factors do not show significant results. However, the two-step regression analysis demonstrates that the intention has a strong relationship with behavior on pedestrian safety. In order to enhance the government efforts to mitigate road accidents, it is efficient to use an education as a medium which helps to change the attitude of road users in the country.
\end{abstract}

\section{Introduction}

Pedestrian is one of the road users that contributes about second highest in the case of road accidents in the world. In 1999, 119,000 of pedestrians were involved in road accidents while 6552 from them was died. In Asian country included Hong Kong and Korea, it is about $70 \%$ from road accidents involved the pedestrians and $50 \%$ was recorded died. The

\footnotetext{
* Corresponding author: raha@uthm.edu.my
} 
total of road accidents involved pedestrian recorded in Middle-East country show increasing $30 \%$ every year [1].

Most of the pedestrians that involved in the road accidents include children, elderly and disabled peoples. Based on the report of World Healthy Organization (WHO), the groups of elderly citizens are more risks to danger compared with the younger citizens as the road users. The probabilities of pedestrians at the age of 65 years old and above will be killed is $71 \%$ compared with the pedestrians age in the range of 15 to 35 years old which is only $20 \%[2]$.

In Malaysia, the case of road accidents involved pedestrians is always increasing at every year as much as the increasing the number of vehicles. Besides that, the case of road accidents involved pedestrians is recorded higher at the city area compared with rural area where the death rate was recorded about 562 cases per year [3]. One of the reasons is the facilities provided for the pedestrians in Malaysia still not fulfill the safety requirement besides the behavior of road users itself [4]. Thus, good condition of pedestrian facilities and good behavior of road users may help to increase the safety for both.

\section{Literature review}

Discuss the previous study that related to the relationship between the pedestrians behavior towards safety and other factors influenced. The main topic that will be discussed is about the psychological and behavior, definition of pedestrian, safety of pedestrian, facilities of pedestrian and Theory of Planned Behavior.

\subsection{Psychological and behavior}

Psychology known as the set of academic, clinical and industrial that related with the explanation and prediction of behavior, thinking, emotion, motivation, personal relation, ability and pathology [5]. The behavior and changes behavior of pedestrian are one of the main aspects in the safety of pedestrian itself. The concept of human behavior can be stated as the one of the idea that related to the emotion with influencing by one action class to another certain situation class [6]. It is the reaction depends to the situation. Moreover, behavior also known as the endurance that will be changed and learned without existed.

\subsection{Pedestrian}

A pedestrian is a person traveling on foot, whether walking or running. In some communities, those traveling using tiny wheels such as roller skates, skateboards, and scooters, as well as wheelchair users [7]. Pedestrian also known as the most high risk users compared with the other class of road users. This is because, pedestrian is more exposed to danger when using the road.

\subsection{Safety of pedestrian}

In Malaysia, there are some organization involved to improve the safety of pedestrian which is IKRAM, JKJR and MIROS. This is because, the amount of road accident including the pedestrian is recorded higher in the urban area compared with the sub-urban area even though the rate of safety is already upgraded. According to the previous study, there are some important points to suggest the facilities for safety of pedestrians included 
flow of vehicles and pedestrians, average of crossing time (gap and acceptance of pedestrian) and previous accident report at the suggestion crossing area [8].

\subsection{Facilities of pedestrian}

Pedestrian crossing system is the most important facilities needed in the area such as school, shopping complex, offices, residential and industrial area. This system needed is to reduce the traffic conflict between vehicles and safety for pedestrian itself. There are some system for pedestrian crossing practiced in Malaysia that included Pelican Crossing, Overpass Crossing and Zebra Crossing [9].

\subsection{Theory of Planned Behavior}

It is one of the theories about relationship between the believing and behavior. The behavior is the most important factors to influence the person to take the action either positive action or negative action [10]. Individual evaluation towards the action taken will be produced two types of believing which is favorable and un-favorable. If a person found out that the action taken give the good feedback, he/she will going through for it but if it is not, he/she will not further the action should be taken. Regarding to the previous study, it was stated that the human behavior give affects the person's intention in establishing a pedestrian wants to cross the road safely or harmful according to the particular circumstances even though the good facility for pedestrians is provided [11].

\section{Methods}

This study is using the Theory of Planned Behavior as the model to determine the behavior of pedestrian towards to the road safety. The components involved as follows:

\subsection{Types of study}

There are two types of study involved which is field work and library research. Field work included to find the information, overview and data surveyed by using survey form provided from the theory of planned behavior (TPB) as sown in Fig. 1. This form will be distributed to the respondent to collect the data according to the pedestrian behavior. Meanwhile, library research involved the activities to find the information from the journal, previous research, thesis, references books, newspaper and internet. All the sources are to perform the objectives of this study.

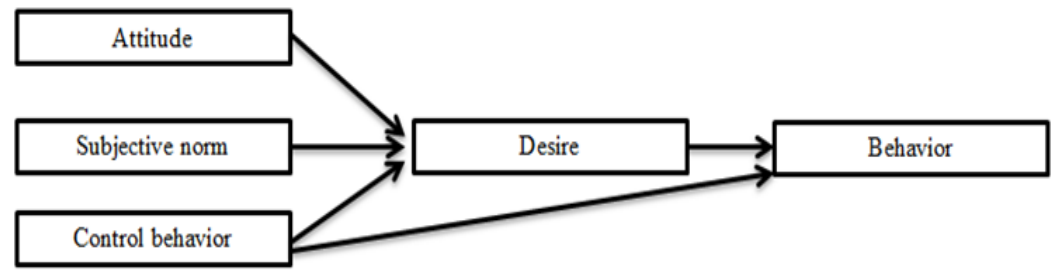

Fig. 1. Model of planned behavior towards behavior with pedestrian safety [10] 


\subsection{Design of study}

To achieve the objectives of this study, there are some steps should be followed in the design of study which is included identify objectives and research problems, data collection, data analysis, final results, conclusion and recommendation of research.

\subsection{Instrument of study}

The instrument of study used is questionnaire. A set of survey questions are provided to achieve the objectives of study. Questionnaires will be distributed to the respondents who are pedestrians in Batu Pahat where a concentration involves a lot of walking activity among road users. The questionnaire consists of three parts, namely Part A, Part B and Part C.

Part A related to respondents' personal information and demographic data such as your gender, race, age, state of life, occupation, level of education and many others. Part B is involves a pedestrian destination, distance, time, walking, etc. part $\mathrm{C}$ is related to the perception of pedestrians where the questions are based on the variables and factors to be taken into account in the theory of planned behavior.

\subsection{Scale of measurement}

The scale of measurement in this study will show the level of agreement from the pedestrian based on the questions provided by survey form. The scale started with 1 to 5 which is totally disagreeing to totally agree. Besides that, the size of samples is collected in randomly. In this study, the population of drivers in Batu Pahat is estimated about 10,000 peoples. However, there is no accurate information to state the total number of drivers in Batu Pahat. Thus, this study used a 200 of sample size to be distributed to the respondents in the study area by refering from previous studies.

\subsection{Area of study}

The site selection factor is very important to collect the data. The area chosen for this study are in Batu Pahat where the focus area in the shopping center, school or residential area. This is because the area was involved a lot of pedestrian activities and movements besides facilities provided such as zebra crossing.

\subsection{Data analysis}

Method of data analysis is the most important to interpret the data collection to become reliable and used conclusion. Thus, statistic method is used by the researcher to understand and describe the relationships between variables in research. There are some analysis involved in this activity which is descriptive analysis, minimum score, trustworthiness analysis and correlation analysis that shown in Table 1 until Table 4 while regression analysis follows the Equation (1). Those analysis works should be analyzed with properly and used the right method to overcome the strong results from this study.

Equation (1) shows the basic formula for the regression:

$$
\mathrm{Y}=a+\sum b i X i
$$


where $\mathrm{Y}$ is score predictor on the dependent variable, $a$ is refer to $\mathrm{Y}$ when $X=0, b i$ is the regression coefficient for the predictor $\mathrm{I}$ and $X i$ is scores on predictor $\mathrm{i}$ (independent variables).

Table 1. Difference between descriptive statistics and inferences [13]

\begin{tabular}{|c|c|c|}
\hline Statistic & Purpose & Statistic \\
\hline Descriptive & $\begin{array}{l}\text { - Describes the characteristics of variables } \\
\text { - Used for drawing the conclusions about the } \\
\text { numerical data / numbered } \\
\text { - Not too common from the sample to the population }\end{array}$ & $\begin{array}{l}\text { Frequency, mean, mode, median, } \\
\text { range, standard deviation, variance, } \\
\text { proportion, percentage, percentage } \\
\text { change, rates, ratios, normal } \\
\text { distribution etc. }\end{array}$ \\
\hline Inferences & $\begin{array}{l}\text { - Describe the relationship between variables } \\
\text { - Describe the characteristics of a selected sample of } \\
\text { the population } \\
\text { - The characteristics of the sample population in } \\
\text { general }\end{array}$ & t-test, ANOVA, Khi Square etc. \\
\hline
\end{tabular}

Table 2. Interpretation and measurement of tendency level based on mean scores [14]

\begin{tabular}{|c|c|c|}
\hline Mean score & Interpretation & Tendency level \\
\hline $1.00-2.33$ & Totally disagree & Low \\
\hline $2.34-3.66$ & Agree & Medium \\
\hline $3.67-5.00$ & Totally agree & High \\
\hline
\end{tabular}

Table 3. Level measurement of alpha Cronbach $(\alpha)[13]$

\begin{tabular}{|c|c|}
\hline Value of Alpha Cronbach ( $\boldsymbol{\alpha})$ & Level measurement \\
\hline$>0.9$ & Excellent \\
\hline$>0.8$ & Good \\
\hline$>0.7$ & Accepted \\
\hline$>0.6$ & Questioned \\
\hline$>0.5$ & Incomplete \\
\hline$>0.4$ & Rejected \\
\hline
\end{tabular}

Table 4. Differences in the interpretation of the coefficients and the strength of the relationship Davis and Guilford [15]

\begin{tabular}{|c|c|c|c|}
\hline \multicolumn{2}{|c|}{ Davis } & \multicolumn{2}{c|}{ Guilford } \\
\hline Coefficient & The strength of the relationship & Coefficient & The strength of the relationship \\
\hline Above 0.70 & Very strong & $0.90-1.00$ & Very strong \\
\hline $0.50-0.69$ & Strong & $0.70-0.90$ & Strong \\
\hline $0.30-0.49$ & Moderate strong & $0.40-0.70$ & Moderate \\
\hline $0.10-0.29$ & Weakinot strong & $0.20-0.40$ & Weak \\
\hline $0.01-0.09$ & Can be ignored & Below 0.20 & Very weak \\
\hline
\end{tabular}

\section{Results and discussions}

This part will describe the results of data collection through questionnaires that were distributed to 200 respondents in the area of Batu Pahat, Johor. The analysis involved as follows:

\subsection{Demographic of respondents}

Table 5 shows the information of respondent demographic regarding to the questionnaire made in this study. 
Table 5. Information of respondent demographic

\begin{tabular}{|c|c|c|}
\hline Item & Frequency & Percentage (\%) \\
\hline $\begin{aligned} \text { Gender } & \\
- & \text { Male } \\
- & \text { Female }\end{aligned}$ & $\begin{array}{c}120 \\
80\end{array}$ & $\begin{array}{l}60 \\
40\end{array}$ \\
\hline Age & & \\
\hline - Below 20 & 60 & 30 \\
\hline$-20-25$ & 100 & 50 \\
\hline$-26-30$ & 20 & 10 \\
\hline - Above 30 & 20 & 10 \\
\hline Type of occupation & & \\
\hline - Government & 20 & 10 \\
\hline - Private & 60 & 30 \\
\hline - Self-employed & 40 & 20 \\
\hline - Student & 80 & 40 \\
\hline Level of education & & \\
\hline - Primary school & 3 & 1.5 \\
\hline - Secondary school & 59 & 29.5 \\
\hline - Training institution & 72 & 36 \\
\hline - IPT & 66 & 33 \\
\hline Experience in using facility? & & \\
\hline - None & 20 & 10 \\
\hline - Sometimes & 60 & 30 \\
\hline - Mostly used & 40 & 20 \\
\hline - Always & 40 & 20 \\
\hline $\begin{array}{l}\text { Experience involving in road } \\
\text { accident? }\end{array}$ & & \\
\hline - Yes & 40 & 20 \\
\hline - No & 160 & 80 \\
\hline
\end{tabular}

\subsection{Characteristic of pedestrians}

Table 6 shows the information of pedestrian characteristic based on their purpose and need regarding to this study. Respondents who intended to work, social activities and personal matter shows the percentage of $10 \%$.

Table 6. Information of pedestrian characteristic

\begin{tabular}{|c|c|c|}
\hline \multicolumn{1}{|c|}{ Item } & Frequency & Percentage (\%) \\
\hline Purposes of pedestrian & 20 & 10 \\
- Work & 20 & 10 \\
- Social activity & 20 & 10 \\
- Personal matter & 80 & 40 \\
- Shopping & 60 & 30 \\
\hline - School/education & 40 & 20 \\
\hline Distance (meter) & 80 & 40 \\
- Below 100 & 20 & 10 \\
- 100-200 & 20 & 10 \\
- 200-300 & 40 & 20 \\
- Abo-350 350 & & \\
Time (minute) & 80 & 40 \\
- Below 10 & 80 & 40 \\
- 10-20 & 20 & 10 \\
- 21-30 & 10 & 5 \\
- Above 45 & 10 & 5 \\
\hline Alternative transportation & & \\
- Public & 40 & 20 \\
- Private car & 70 & 35 \\
- Motorcycle & 80 & 40 \\
- Bicycle & 10 & 5 \\
\hline
\end{tabular}

While who would like to go to store or shopping center shows $40 \%$ and $30 \%$ to the school or educational institution. According to the distance taken by pedestrians, it is shows that $20 \%$ respondents are walking less than $100 \mathrm{~m}$ and more than $350 \mathrm{~m}$. Meanwhile, who is 
walking about $100 \mathrm{~m}$ to $200 \mathrm{~m}$ shows $40 \%$. It is only $10 \%$ respondents that walking about $200 \mathrm{~m}$ until $300 \mathrm{~m}$ and $300 \mathrm{~m}$ until $350 \mathrm{~m}$.

For the time taken by pedestrians to go to the destination, it is about $40 \%$ from the respondents achieved less than 10 minutes and in the range 10 minutes to 20 minutes. Then, respondents that achieved the time taken about 21 minutes to 30 minutes is about $10 \%$ while it is only $5 \%$ respondents that achieved time taken in the range 31 minutes to 45 minutes and more than 45 minutes in this survey. Regarding to the percentage of alternative transportation, it is shows that $20 \%$ from the respondents use the public transport while $30 \%$ uses private car. The highest percentages can be seen that the most respondents use the motorcycle which is about $40 \%$ while it is only $5 \%$ that use a bicycle.

\subsection{Minimum score}

The value of minimum score in this study was summarized in Table 7 where it is based on the theory of planned behavior regarding to the feedback from the pedestrian.

Table 7. Summarization of minimum score

\begin{tabular}{|c|c|c|c|}
\hline Variables & No. of items & Average of min score & Results \\
\hline Attitude & 4 & 4.26 & Agree \\
\hline Subjective norms & 5 & 3.17 & Agree \\
\hline Control behavior & 4 & 3.94 & Agree \\
\hline Desire & 3 & 3.90 & Agree \\
\hline Behavior & 2 & 4.75 & Agree \\
\hline
\end{tabular}

\subsection{Analysis of trustworthiness}

The level of trustworthiness is depend on the theory of alpha Cronbach where the value of alpha will produces the good results and accepted as shown in Table 8 .

Table 8. The value of alpha Cronbach

\begin{tabular}{|c|c|c|c|}
\hline Variables & No. of items & Value of alpha Cronbach & Results \\
\hline Attitude & 4 & 0.7 & Accepted \\
\hline Subjective noms & 5 & 0.7 & Accepted \\
\hline Control behavior & 4 & 0.6 & Accepted \\
\hline Desire & 3 & 0.6 & Accepted \\
\hline Behavior & 2 & 0.8 & Good \\
\hline
\end{tabular}

\subsection{Analysis of correlation}

From the analysis, the value of correlation between subjective norms and attitude of pedestrian shows vice versa. It is means the subjective norm is not influencing the attitude of pedestrian according to the safety. Besides that, the control behavior and desire towards behavior shows the same result as mention before. It is can be explained in the situation when a pedestrian show a good attitude and polite when crossing the street, pedestrian will be in safe.

\section{Conclusions}

Based on the main objective of this study is to identify the behavior of pedestrian safety is seen to have achieved the objectives. This is because the results from the analysis show the significance of the factors involved. Attitudes, subjective norms, behavioral control and the 
desire to influence the behavior of pedestrians on the road such as attitude in a hurry to pass, the influence of family and close friends, the sensitivity of the surrounding state and others. Meanwhile, the objective of the study to apply the theory of planned behavior is achieved when the analysis was a relationship between the variables involved on the behavior of pedestrian safety in urban area such as Batu Pahat, Johor.

\section{References}

[1] C.A. O'Flaherty, M.H. Parkinson, Movement on city centre footway, Traffic Engineering and Control, 13, $434-438$ (2006)

[2] World Health Organization, World Report on Traffic and Injury Prevention, Geneva, (2011)

[3] Jabatan Keselamatan Jalan Raya, Laporan Kemalangan Jalan Raya, Kuala Lumpur, (2007)

[4] Malaysian Institute of Road Safety Research, Laporan Kemalangan Jalan Raya 2011, Kuala Lumpur (2011)

[5] R. Lancaster, R. Ward, Management of work and age related road safety, Entec UK Limited for The Health and Safety Executive and Scottish Executive, (2002)

[6] H.C. Triandis, E.R. Hall, R.B. Ewen, Member heterogeneity and dyadic creativity, Human Relations, 18(1),33 - 55 (1965)

[7] Austroads, Road Safety Audit, Austroads Publication, Sydney, (2009)

[8] H. Davies, M.A. Winett, Why do Pedestrian Accidents Happen?, PTRC Proceedings, P365, 315 - 324 (2012)

[9] M.R. Ibrahim, M.R. Karim, F.A. Kidwai, The Effect of digital count-down display on signalized junction performance, American Journal of Applied Sciences, 5(5), 497$482(2008)$

[10]I. Ajzen, The theory of planned behaviour, Organizational Behavior and Human Decision Processes, 50, 179 - 211 (1991)

[11]D. Evans, P. Norman, Understanding pedestrians road crossing decisions: An application of the theory of planned behaviour, Health Education Research, 13(4), 418 -489 (2003)

[12]M.O. Azuan, Analisis Tingkah Laku dan Sikap Pemandu Kenderaan Kecil Terhadap Kelajuan, Thesis, Universiti Tun Hussein Onn Malaysia, (2012)

[13]Y.P. Chua, Kaedah Penyelidikan - Kaedah dan Statistik Penyelidikan - Buku 1, McGraw Hill Education, Kuala Lumpur, (2006)

[14]Norhayati, Persepsi Pelajar Terhadap Sikap, Pengetahuan dan Kemahiran dalam Mata Pelajaran Vokasional (MPV) di Sekolah Menengah Akademik di Batu Pahat, Johor, Master Thesis, Kolej Universiti Teknologi Tun Hussein Onn, (2005)

[15]R.D. Yockey, SPSS Demystified. A Step-By-Step Guide to Successful Data Analysis, Pearson Education, (2008) 